\title{
Hepatit B Hastalarında Regülatör T Hücre ve Salınan İmmünmodülatör Sitokin IL-10 Düzeylerinin Değerlendirilmesi
}

\author{
Investigation of Regulatory T Cells and Secreted \\ Immunomodulatory Cytokine IL-10 Levels in Patients \\ with Hepatitis B
}

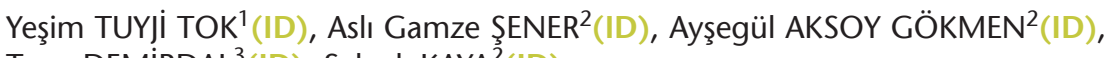

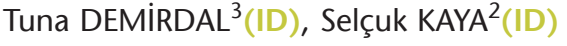 \\ 1 isstanbul Üniversitesi Cerrahpaşa Tıp Fakültesi, Tıbbi Mikrobiyoloji Anabilim Dalı, İstanbul. \\ ${ }^{1}$ Istanbul University Faculty of Cerrahpasa Medicine, Department of Medical Microbiology, Istanbul, Turkey. \\ 2 İzmir Katip Çelebi Üniversitesi Atatürk Eğitim ve Araştırma Hastanesi, Tıbbi Mikrobiyoloji Kliniği, İzmir. \\ 2 Izmir Katip Celebi University Atatürk Training and Research Hospital, Clinic of Medical Microbiology, Izmir, Turkey. \\ 3 İzmir Katip Çelebi Üniversitesi Atatürk Eğitim ve Araştırma Hastanesi, Enfeksiyon Hastalıkları ve Klinik Mikrobiyoloji \\ Kliniği, İzmir. \\ ${ }^{3}$ Izmir Katip Celebi University Atatürk Training and Research Hospital, Clinic of Infectious Diseases and Clinical \\ Microbiology, Izmir, Turkey.
}

* Bu çalışma, birinci yazarın uzmanlık tezi olarak yapılmış ve 4. Klinik Mikrobiyoloji Kongresi (Klimud) (8-12 Kasım 2017, Antalya)'nde sözel bildiri olarak sunulmuştur.

Makale Atıfı: Tuyji Tok Y, şener AG, Aksoy Gökmen A, Demirdal T, Kaya S. Hepatit B hastalarında regülatör T hücre ve salınan immünmodülatör sitokin IL-10 düzeylerinin değerlendirilmesi. Mikrobiyol Bul 2020;54(2):266-278.

\section{ÖZ}

Hepatit B, tedavi stratejilerinde büyük gelişmeler kaydedilmesine rağmen, halen dünya çapında önemli sağlık sorunları arasında yer almaktadır. Hepatit B virüsü (HBV) karaciğer hücresine girerek kendini replike etmekte ve antijen salınımıyla eş zamanlı olarak regülatör T hücre (Treg), T helper $17\left(\mathrm{Th}_{17}\right)$, T helper $1\left(T h_{1}\right)$ ve T helper $2\left(T_{2}\right)$ hücreleri dahil olmak üzere birçok zıt etkili hücrenin rol aldığı immün yanıtı indüklemektedir. Treg hücrelerinin temel fonksiyonu enfeksiyona karşı uygun bağışıklık yanıtının geliştirilmesi, bağışıkık yanıtının gerekmediği durumda ise baskılanmasını sağlamaktır. Treg hücreleri, "Transforming Growth Factor-Beta" ve interlökin (IL)-10 benzeri sitokinlerin salınımı yoluyla veya kontakt bağımlı olarak efektör T hücrelerini baskılayabilmektedir. Bir yandan HBV'ye özgül T hücre yanıtını baskılayarak karaciğeri immünopatolojik hasardan korurken bir yandan da viral persistansa, siroz, hepatoselüler kanser (HSK) ve otoimmünite gelişimine neden olabilen Treg'lerin mekanizmaları henüz net değildir. Bu çalışmada, hepatit B hastalarında Treg hücrelerinin ve salınan IL-10 sitokin düzeylerinin birlikte değerlendirilmesinin, hastalığın ağırlığını ve seyrini öngörmede kullanışı olup olamayacağını araştırmak amaçlanmıştır. Enfeksiyon hastalıkları poliklinik/servisine başvuran 61 HBV enfeksiyonlu hasta ile 30 sağlıklı kontrol olmak üzere toplam 91 gönüllüden periferik kan numuneleri alınmıştır. Akım sitometrisi yöntemiyle, yakın za- 
manda tanımlanan belirteçler de kullanılarak, $C D 4^{+} \mathrm{CD} 25^{\text {high }} \mathrm{FOXP} 3^{+} \mathrm{CD} 152^{+} \mathrm{CD} 127^{\text {low }}$ Treg hücre dağıIımları araştırılmıştır. İmmün modülatör hücreler tarafından salınan IL-10 sitokin düzeyi ise kantitatif ELISA yöntemiyle çalışılmışır. Akut hepatit B hastalarının Treg hücre yüzdeleri normal sınıların (\%2-4) altında (medyan $=\% 1.50,0.6-3.5)$ saptanmış, aradaki fark istatistiksel olarak anlamlı $(p=0.005)$ bulunmuştur. Kronik hepatit B hastalarının Treg düzeyleri kontrol grubuna göre yüksek bulunmuş $(p<0.05)$, hastalığın tanısı, evrelemesi ve takibinde kullanılan parametrelerle de ilişkili olduğu görülmüştür. Tüm hepatit B klinik evrelerinde IL-10 düzeyleri sağlıklı kontrollerle (medyan= 11.7, 17.3-44.9) karşılaştııılığında anlamlı düzeyde yüksek bulunmuştur $(p<0.05)$. IL-10 düzeylerinin ise Treg hücre ile paralel olarak, HBV DNA yükü ve $\mathrm{HBsAg}$ düzeyleri ile korelasyon gösterdiği saptanmıştır $(r=0.48, p<0.02)$. Treg hücrelerinin ve ilişkili sitokin IL-10'un HBV enfeksiyonunun immünolojisinde önemli rolü olduğu, hastalığın takibinde ve Treg hücreyi hedef alan yeni tedavi stratejilerinin geliştirilmesinde umut vadettiği düşünülmüştür.

Anahtar kelimeler: Hepatit B virüsü; regülatör T-hücre; akım sitometrisi.

\section{ABSTRACT}

Hepatitis B infection is still among the most important public health problems worldwide, even great improvements have been made in the treatment strategies. Hepatitis B virus (HBV) replicates itself by entering the liver cells and simultaneously with the antigen release, many antagonistic immune responses are induced by the regulatory cells including $T$ cell $(T r e g)$, $T$ helper $17\left(\mathrm{Th}_{17}\right)$, T helper $1\left(\mathrm{Th}_{1}\right)$ and $\mathrm{T}$ helper $2\left(\mathrm{Th}_{2}\right)$ cells. The main function of Treg cells is to develop an appropriate immune response against infection and to suppress the immune response if it is not required. Tregs suppress the effector $\mathrm{T}$ cells via secreting immune system supressor cytokines such as Transforming Growth Factor-Beta and interleukin (IL)-10 or contact dependent way. Tregs protect cells from immunopathologic damage of HBV specific T cell immune response and also cause viral persistence, cirrhosis, hepatocellular carsinoma (HCC) and autoimmunity but the mechanisms are not clear, yet. In this study, we aimed to determine whether evaluation of Treg cells and cytokine IL-10 levels together in hepatitis B patients is useful that may indicate the disease survey and response to the treatment. The peripheral blood samples of ninety-one volunteers, including $61 \mathrm{HBV}$ infected patients and 30 healthy controls selected from applicants of Infectious Diseases Outpatient/Clinic Service, were taken. Their $\mathrm{CD} 4^{+} \mathrm{CD} 25^{\text {high }} \mathrm{FOXP} 3^{+} \mathrm{CD} 152^{+} \mathrm{CD} 127^{\text {low }}$ Treg cell distribution were measured by flow cytometry method, using the recently defined markers. The level of IL-10 cytokine released by immunomodulatory cells was determined by quantitative ELISA method. Treg cell percentages of the patients with acute hepatitis $B$ were below the normal range $(2-4 \%)$ (median= $1.50 \%, 0.6-3.5)$ and the difference was statistically significant $(p=0.005)$. Treg cell percentages of the patients with chronic hepatitis $B$ were higher than the control group $(p<0.05)$, and it was found to be related to the parameters used in the diagnosis, staging and follow-up of the disease. IL-10 levels were significantly higher in all hepatitis B clinical stages compared to the healthy controls (median=11.7, 17.3-44.9) $(p<0.05)$. Also, in parallel with Treg cells, IL-10 levels were correlated with HBV DNA load and HBsAg levels $(r=0.48, p<0.02)$. Treg cells and the related cytokine IL-10 are thought to play an important role in the immunology of HBV infection and therefore, promising to follow up the disease and to develop new therapeutic strategies targeting the Treg cell.

Keywords: Hepatitis B virus; regulatory T-cell; flow cytometry.

\section{Gíriş}

Hepadnaviridae ailesinden hepatit B virüsü (HBV), RNA aracılığı ile replike olan ve konak genomuna bütünleşen, sitopatik olmayan, hepatotropik, kısmen çift iplikçikli küçük DNA virüsüdür ${ }^{1,2}$. HBV enfeksiyonunun doğal seyri çiçek aşısı kampanyası sonrasında gelişen "ikterus epidemisi" ile ilk kez 1885 yılında Lurman tarafından tanımlanmış olsa da halen, karaciğerin akut veya kronik enflamasyonuna neden olarak, siroz ve hepatoselüler kansere (HSK) yol açabilmesiyle önemli sağlık sorunlarından biri olmaya devam etmektedir ${ }^{3,4}$. Dün- 
yada her yıl 620 bin hastanın geç komplikasyonlar nedeniyle kaybedildiği bildirilmektedir ${ }^{5}$. Türkiye'de HBsAg pozitifliği oranı bölgeden bölgeye değişmekle birlikte ortalama \%4'tür ve ülkemiz HBV enfeksiyonu açısından orta düzeyde endemik bölgede yer almaktadır ${ }^{6}$.

HBV, inkübasyon süresi içinde hepatosit içine girerek replike olmakta, kendine ait antijenleri üretmekte ve konağın "toll-like reseptörleri (TLR)" de yabancı olan bu yapıları ve mikroorganizma yüzeyindeki "pathogen-associated molecular patterns (PAMP)"ları tanıyarak immün yanıtı başlatmaktadır ${ }^{7}$. İmmün sistem aracılı eliminasyon mekanizmaları enfekte hücreleri ortadan kaldırıp enfeksiyonu sonlandırmaya çalışır ve kalıcı nekroenflamatuvar aktivite karaciğer hasarına neden olabilir. Bu süreçte vücudun immün matürasyonu ve immün yanıtın şiddeti hepatitin seyrini belirlemektedir. Aktif enflamasyon yanıtının tersi yönde fonksiyon gören regülatör T hücreler (Treg) ise diğer birçok lenfosit alt grubu ile birlikte karaciğer sinüzoidlerinde yer alır ve immün toleranstan sorumludur $^{8}$. Kronik hepatit B (KHB) enfeksiyonunda Treg hücrelerinin zararlı etkileri görülmekte; sağlıklı kontrollere ve akut enfeksiyona göre artmış düzeyleri viral replikasyon/yük ile korelasyon göstermektedir ${ }^{7,9}$. Immün modülatör hücrelerden üretilen interlökin (IL)-10; interferon-alfa (IFN- $\alpha$ ) üretimini inhibe ederek dentritik hücre apoptozisini uyarmakta, ardından antijen sunucu hücreleri baskılayarak $C D 8^{+} \mathrm{T}$ hücre uyarılmasını zayıflatmakta ve HBV-spesifik T hücre yanıtını baskılamaktadır ${ }^{10}$. Periferik kan Treg düzeyi takibinin, hastalığın karaciğer yetmezliğine progresyonuna ilişkin yol gösterici bir belirteç olarak kullanılabileceği ayrıca immün dengeyi yeniden oluşturmasıyla kronik hepatit B (KHB)'de karaciğer doku hasarını önleyici tedavide kullanılabileceği yönünden bulgular mevcuttur $^{11}$. Diğer taraftan insan ve hayvan kanser modellerinde yapılan çalışmalar, bu hücrelerin tümör progresyonunu arttırdığını doğrulamıştı ${ }^{12,13}$ ayrıca Treg hücrelerin akut fazda azaltılmasının enfeksiyonun temizlenmesine terapötik etkisi olabileceği ya da aşının etkinliğini arttırabileceği ileri sürülmüştür ${ }^{14}$.

Bu çalışmada, HBV spesifik T hücre yanıtını baskılayarak karaciğer doku hasarını ve enflamasyonunu azaltan Treg hücre ve immün modülatör hücrelerden salınan IL-10 sitokin düzeyinin birlikte değerlendirilmesinin, hastalığın ağırlığını ve seyrini öngörmede kullanışı bir belirteç olup olamayacağını araştırmak amaçlanmıştır.

\section{GEREÇ ve YÖNTEM}

Bu çalışma, İzmir Katip Çelebi Üniversitesi Klinik Araştırmalar Etik Kurulu onayı ile gerçekleştirildi (Tarih: 12.11.2015 ve Karar no: 153) ve çalışmaya katılmayı kabul eden kişilerin gönüllü onamı alındı.

\section{Hasta Seçimi}

Hastanemiz enfeksiyon hastalıkları poliklinik/servisine başvuran ve hepatit B enfeksiyonu tanısı alan, yaşları 32-54 arasında değiş̧en, 30 kadın/31 erkek olmak üzere 61 hasta ile portör taraması için başvuran serolojik viral hepatit göstergeleri negatif olan, yaşları 36-62 arasında değişen, 15 kadın/15 erkek olmak üzere 30 sağlıklı kontrol grubu olmak üzere toplam 91 kişi çalışmaya dahil edildi. Hazırlanan anket formuna yaş, cinsiyet, mes- 
lek, yaşadıkları bölge gibi demografik veriler ile ek hastalık/ilaç kullanımı öyküsü, semptomları, hepatit B için olası bulaş yolu (aile öyküsü, hastaneye yatış/ameliyat öyküsü, kan/ organ nakli, riskli meslek, intravenöz madde bağımlılığı, tatuaj varlığı vb.) kaydedildi. HBV DNA düzeyi, serolojik (anti-HAV, anti-HIV, anti-HCV, Delta Ag/Ab, HBsAg, anti-HBs, $\mathrm{HBeAg}$, anti-HBe, anti-HBc $\lg \mathrm{M}$, anti-HBc IgG) ve hastane bilgi sisteminden taranarak biyokimyasal [eritrosit sedimentasyon hızı (ESH), lökosit, hemoglobin, trombosit sayıları, koagülasyon, alfa-fetoprotein (AFP), karaciğer enzimleri, bilirubin düzeyleri], radyolojik [ultrasonografi (USG)/bilgisayarlı tomografi (BT)] ve patolojik (karaciğer biyopsisi) tetkik sonuçları formlara kaydedildi. Çalışmaya akut ve kronik evredeki hepatit B hastaları dahil edildi. Kronik HBV enfeksiyonu taşıyan hastalar, "European Association for the Study of the Liver (EASL)" klinik uygulama rehberinin evrelemesine göre (Tablo I); (I) HBeAg pozitif kronik enfeksiyon, (ii) HBeAg pozitif kronik hepatit, (iii) HBeAg negatif kronik enfeksiyon, (iv) HBeAg negatif kronik hepatit evrelerinde olmalarına göre gruplandı ${ }^{15}$. Çalışmaya dahil edilme kriterleri; örnek alımından altı ay öncesine kadar immün modülatör ilaç ya da tedavi almamış olmak, hepatit $A$ virüsü (HAV)/hepatit $C$ virüsü (HCV)/hepatit delta virüsü (HDV)/hepatit E virüsü (HEV) ve insan immün yetmezlik virüsü (HIV)'ne bağlı ya da alkolik/otoimmün karaciğer hastalığı, herhangi bir malignansi veya diğer ciddi sistemik hastalıkları bulunmamak şeklinde belirlendi.

\section{Numune Alımı ve Hazırlanması}

Hasta ve kontrol grubundan klinik örnek olarak EDTA'lı tüpe alınan periferik kan numuneleri akım sitometrisi yöntemiyle çalışıldı, eş zamanlı jel içeren tüpe de alınan örnekler santrifüj edildikten sonra elde edilen serumlar $-40^{\circ} \mathrm{C}^{\prime}$ de "enzyme-linked immuno sorbent assay (ELISA)" çalışma gününe kadar saklandı.

\section{Akım Sitometrisi Çalışması}

Treg hücre yüzde dağılımlarını belirlemek için üretici firmanın önerileri doğrultusunda; önce PC5-CD4, ECD-CD25, PE-CD152, FITC-127 floresan işaretli antikorlar kullanılarak yüzey, daha sonra da perforan/fiksatif enzimle muamele edilerek PC7-FOXP3 antikorunun hücre içi boyanması protokolü uygulandı. Yedi renkli akım sitometri ciha-

Tablo I. EASL Klinik Uygulama Rehberine Göre Hepatit B Virüsü (HBV) ve Karaciğer Hasarı Belirteçlerine Dayalı Kronik HBV Enfeksiyonu Olan Hastaların Evrelemesi

\begin{tabular}{lcccc}
\multicolumn{4}{c}{ HBeAg pozitif } & \multicolumn{2}{c}{ HBeAg negatif } \\
\hline HBsAg & Yüksek & Yüksek/Orta & Düşük & Orta \\
HBeAg & Pozitif & Pozitif & Negatif & Negatif \\
HBV DNA & $>10^{7} \mathrm{IU} / \mathrm{ml}$ & $10^{4}-10^{7} \mathrm{IU} / \mathrm{ml}$ & $<2000 \mathrm{IU} / \mathrm{ml}$ & $>2000 \mathrm{IU} / \mathrm{ml}$ \\
ALT & Normal & Yüksek & Normal & Yüksek \\
Karaciğer hasarı & Yok/Minimal & Ilımlı/Ağır & Yok & Ilımlı/Ağır \\
Eski terminoloji & İmmün toleran & İmmün reaktif & İnaktif taşıyıcı & HBeAg negatif \\
& & HBeAg pozitif & & kronik hepatit \\
\hline ALT: Alanin aminotransferaz. & & &
\end{tabular}


zında (FC 500 Cytometry Beckman Coulter, Inc. ABD) FSC/SSC hücre dağılımı üzerinde uygun lenfosit kapısında 10.000 hücre sayılıp izotipik kontrolle diğerlerinden ayrılan $\mathrm{CD}^{+}, \mathrm{CD} 25^{\text {high }}$ hücre alt grubunun en parlak hücreleri seçilerek aynı zamanda FoxP3, CD127 ${ }^{\text {low }}$ (Interleukin-7 Receptor alpha, IL-7Ra), CD152+ (CTLA-4) eksprese edenlerinin yüzde oranları ölçüldü. Treg hücrelerin periferik kanda normal dağılım aralığı olan \%2-4 üzerindeki değerler artış olarak kabul edildi (Şekil 1).

\section{Kantitatif IL-10 Sitokin Ölçümü}

İmmün modülatör Treg hücre tarafından sekrete edilen IL-10 sitokin düzeyi ölçümü için ticari kantitatif ELISA kiti kullanılarak 96 kuyucuklu U-tabanlı plaklarda serum örnekleri üretici firmanın önerileri doğrultusunda (DIAsource Immunoassays SA, Belçika) tek seferde çalışıldı.

\section{Virolojik Değerlendirme}

Serum HBsAg, anti-HBs, anti-HBc, HBeAg, anti-HBe, anti-HCV, anti-HIV düzeyleri ticari ELISA kitleri (Architect Plus i2000 SR, Abbott, ABD), HBV DNA viral yük ise kantitatif gerçek zamanlı polimeraz zincir reaksiyonu (Rt-PCR) (Cobas X480, Hamilton, Roche, İsveç) ile ölçüldü. HBV DNA saptama limiti 15 kopya/ml olarak belirlendi.

\section{İstatistiksel Değerlendirme}

Çalışmada elde edilen bulgular değerlendirilirken, istatistiksel analizler için "Statistical Package for Social Sciences (SPSS) 22.0" programı kullanıldı. Sürekli değişkenlerin nor-

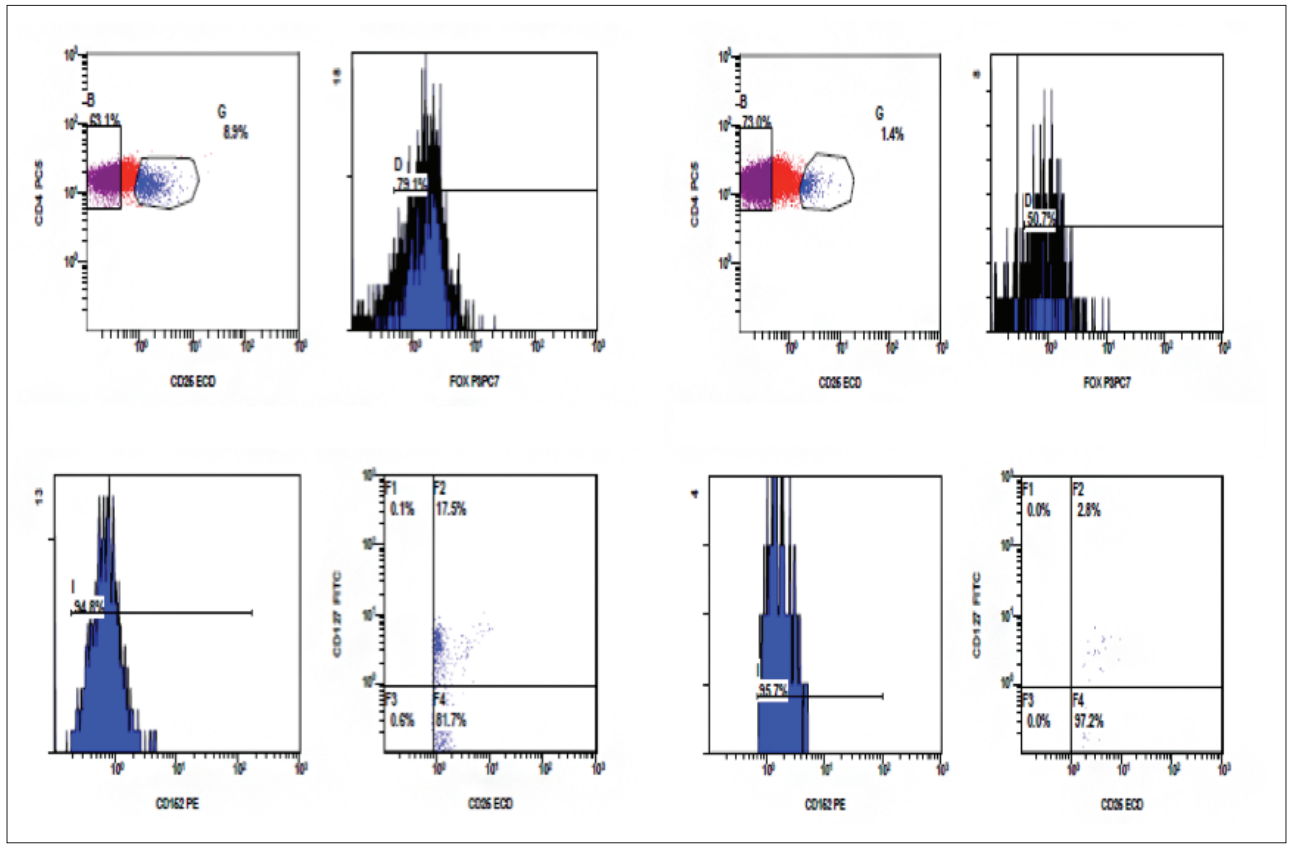

Şekil 1. Treg hücre yüzdelerinin akım sitometrisi ölçümü. 
mal dağılıma uyumu Shapiro-Wilks testi ile analiz edildi. Grup varyanslarının homojenliği Levene's testi ile değerlendirildi. Normal dağılım gösteren ve grup varyanslarının homojen olduğu parametrelerde iki grup ortalaması arasındaki farkın anlamlılı̆ı Student's t-testi ile değerlendirildi, sonuçlar ortalama ve standart sapma ile ifade edildi. Parametrik olmayan verilerin karşılaştırılmasında Mann-Whitney $U$ ve Kruskall-Wallis testi kullanıldı, sonuçlar medyan ve 1.-3. çeyrek değerleri (medyan, Q1-Q3) olarak ifade edildi. Spearman korelasyon analizi ile değişkenler arasındaki ilişkilere bakıldı. Sonuçlar \%95 güven aralığında, anlamlılık $\mathrm{p}<0.05$ düzeyinde değerlendirildi.

\section{BULGULAR}

Hastaların çalışmaya alınmak üzere yapılan değerlendirmelerinde; \%27.9'u HBV'yi hangi yolla aldıklarını bilmediklerini ve başka nedenlerle hastaneye başvurularında yapılan tetkiklerde tanı aldıklarını ifade ederken, en sık bulaş yolunun aile içi olduğu (27, $\% 44.3$ ) ve aile bireylerinin yarısına yakınında (birinci ve ikinci derece akrabalarında ve eşlerinde, $n=29, \% 47.5)$ HBV pozitifliğinin mevcut olduğu, bunu cerrahi girişim ( $n=9$, \%14.8) ve kan transfüzyonlarının ( $n=5, \% 4.9)$ takip ettiği görülmüştür. Hepatit $B$ bulaşı açısından riskli mesleklerde çalışan (laboratuvar teknisyeni, hemşire, berber) kişilerin hastaların \%9.8'ini oluşturmakta olduğu belirlenmiştir. Hastaların anamnez ve sistemik muayenelerine dayanarak, büyük oranda hepatit B'yi asemptomatik (\%52.5) geçirdikleri, akut evrede en sık halsizlik, yorgunluk, kas ağrısı gibi özgül olmayan yakınmaların (\%18) görüldüğü, diğer bulguların sırasıyla; ikter (\%13.1), bulantı (\%9.8), idrar renginde koyulaşma (\%4.9) ve kaşıntı (\%1.6) şeklinde ortaya çıktığı izlenmiştir.

HBV DNA yük, HBeAg pozitif kronik enfeksiyon ve HBeAg pozitif kronik hepatit dönemi KHB hasta gruplarda en yüksek değerlere ulaşırken (sırasıyla; $10^{7} \mathrm{kopya} / \mathrm{ml}$ ve $10^{5}$ kopya/ml), HBeAg negatif kronik enfeksiyon ve HBeAg negatif kronik hepatit gruplarında düşük düzeylerde saptanmıştır. Hepatit B hasta gruplarının alanin aminotransferaz (ALT) düzeyleri sağlıklı kontrollerle karşılaştırıldığında yüksek bulunmakla birlikte bu fark yalnız akut hepatit B (AHB) grubunda istatistiksel olarak anlamlı $(p<0.01)$; INR ve total bilirubin düzeyleri AHB grubunda yüksek bulunurken diğer gruplarda normal sınırlar içinde saptanmıştır. Histolojik aktivite indeksi (HAl) bakılabilen gruplarda ( $n=38)$; HBeAg pozitif kronik hepatit $\left(\mathrm{HAl}_{\text {ort }}=7\right)$ ve $\mathrm{HBeAg}$ negatif kronik hepatit dönemleri $\left(\mathrm{HAl}_{\text {ort }}=6\right)$ ile $\mathrm{HBe}$ Ag negatif kronik enfeksiyon ( $\mathrm{HAl}_{\text {ort }}=3$ ) arasında istatistiksel olarak anlamlı fark izlenmiştir $(\mathrm{p}<0.01)$ (Tablo II).

Hepatit B hastalarında virüse spesifik immün regülasyonun bir belirteci olarak Treg hücre yüzdesi ve bu hücrelerden salınan IL-10 sitokin düzeyinin klinik evrelere göre dağılımı değerlendirildiğinde; AHB evresinin genellikle kısa sürmesi (ortalama altı hafta) ve asemptomatik de geçirilebilmesi nedenleriyle ${ }^{16,17}$, bu hasta grubu sayısının düşük olması ve normal dağılım göstermemesi sonucu (Shapiro-Wilk, $p=0.045)$, Treg hücre yüzdelerinin sağlıklı kontrol grubu ile karşılaştırılması nonparametrik Mann-Whitney $U$ testi ile değerlendirilmiş ve akut evredeki hastaların Treg hücre yüzdeleri normal dağılım aralığından (\%2-4) ${ }^{18}$ daha düşük (medyan= 


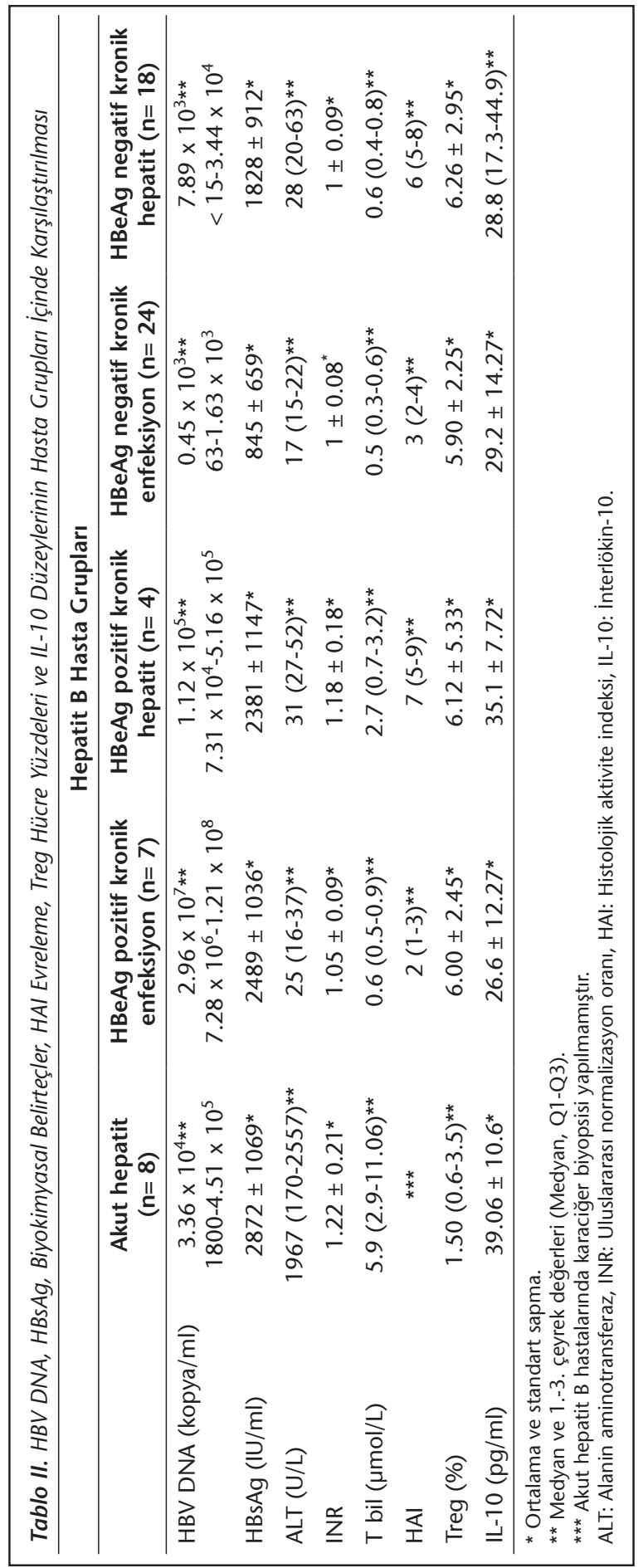


\%1.50, 0.6-3.5) saptanmıştır, aradaki fark istatistiksel olarak anlamlı bulunmuştur ( $\mathrm{p}=$ 0.005). Normal dağılım gösteren KHB grupları Treg hücre dağılımının sağlıklı kontroller ile arasındaki farkın anlamlılığı student's t test ile değerlendirilmiş; HBeAg pozitif kronik enfeksiyon $( \pm S D=2.45$, ortalama $=\% 6.00)$, HBeAg pozitif kronik hepatit $( \pm S D=5.33$, ortalama $=\% 6.12)$, HBeAg negatif kronik enfeksiyon $( \pm S D=2.25$, ortalama $=\% 5.90)$ ve $\mathrm{HBeAg}$ negatif kronik hepatit dönemi $( \pm \mathrm{SD}=2.95$, ortalama $=\% 6.26)$ hastaların Treg hücre yüzdeleri sağlıklı kontrollerle $( \pm S D=1.01$, ortalama $=\% 4.073$, medyan= \%4.1) karşılaştırıldığında anlamlı düzeyde yüksek bulunmuştur (Tablo II). Tüm hepatit B klinik evreleri ve sağlıklı kontroller arası Treg hücre yüzdeleri çoklu karşılaştırılması Kruskal-Walis testiyle değerlendirilmiş; sağlıklı kontrollerle AHB, HBeAg pozitif kronik enfeksiyon, HBeAg pozitif kronik hepatit, $\mathrm{HBeAg}$ negatif kronik enfeksiyon ve $\mathrm{HBeAg}$ negatif kronik hepatit dönemi hastaları arasında (sırasıyla $p=0.005, p=0.018, p=0.018, p=0.017, p=0.028$ ), AHB hastalarıyla da KHB hastaları arasında (HBeAg pozitif kronik enfeksiyon $\mathrm{p}=0.001, \mathrm{HBeAg}$ pozitif kronik hepatit $p=0.001$, HBeAg negatif kronik enfeksiyon $p=0.002$, HBeAg negatif kronik hepatit $p=0.002$ ) istatistiksel olarak anlamlı fark görülmüştür (Şekil 2).

Tüm hepatit B klinik evreleri arası IL-10 sitokin düzeyi farkının istatistiksel önemi Kruskal-Wallis testiyle değerlendirilmiş; $\mathrm{AHB}$ evresindeki hastaların $( \pm \mathrm{SD}=10.67$, ortalama $=$ 39.6), HBeAg pozitif kronik enfeksiyon ( $\pm \mathrm{SD}=12.27$, ortalama= 26.6), HBeAg pozitif kronik hepatit $( \pm S D=7.72$, ortalama $=35.1)$, HBeAg negatif kronik enfeksiyon $( \pm S D=14.27$, ortalama $=29.2)$ ve $\mathrm{HBeAg}$ negatif kronik hepatit dönemi $( \pm \mathrm{SD}=53.25$, median= 28.85) gruplarının IL-10 düzeyleri sağlıklı kontrollerle (medyan= 11.7, 17.3-44.9) karşılaştırıldığında anlamlı düzeyde yüksek bulunmuştur ( $p<0.05$ ) (Şekil 2). HBsAg ile HBV DNA düzeyleri ( $r=0.61, p=0.006)$, HBsAg ile IL-10 düzeyleri $(r=0.48, p<0.02)$ ve KHB hastalarında HBsAg ile Treg hücre yüzdeleri $(r=0.63, p=0.028)$ arasında pozitif korelasyon izlenmiştir (Şekil 3).

Akım sitometri analizinde Treg hücreleri belirlemek amacıyla $C D 4^{+} C D 25^{\text {high }}$ en parlak floresans boyanan alanda seçilen hücre popülasyonu ile diğer Treg belirteci olarak kul-
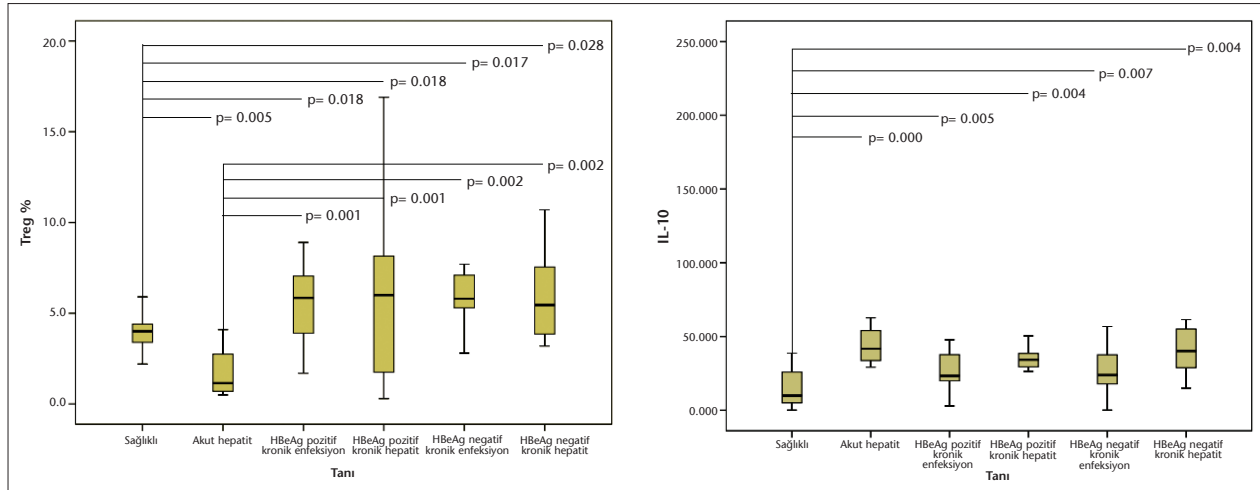

Şekil 2. Çalışma grupları arasında Treg \% ve IL-10 değerlerinde saptanan istatistiksel olarak anlamlı farkın Box-plot grafiği ile gösterilmesi. 


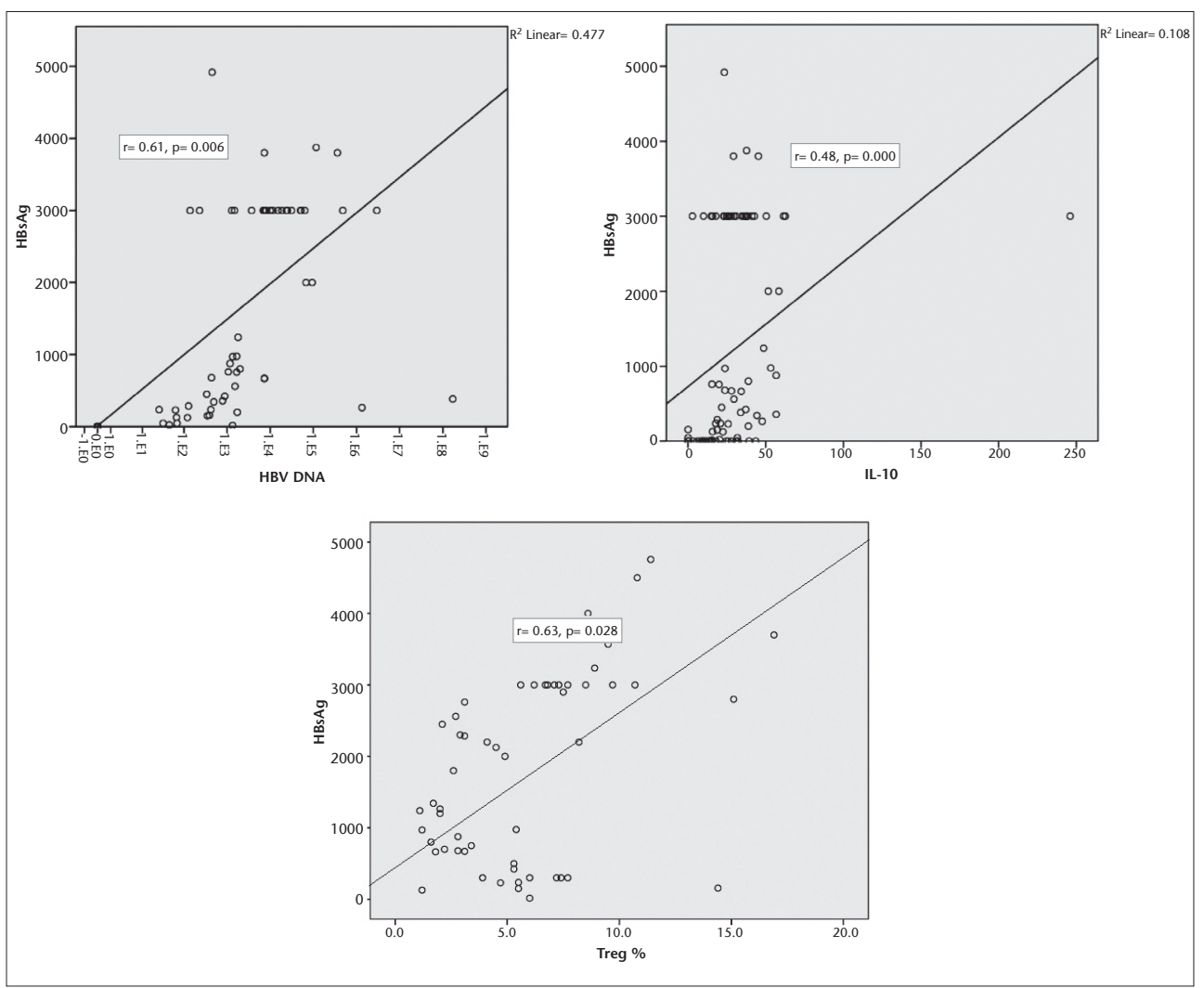

Şekil 3. Sırasıyla, HBsAg ile HBV DNA düzeyleri, HBsAg ile IL-10 düzeyleri ve kronik hepatit $B$ hastalarında HBsAg ile Treg hücre yüzdeleri arasında saptanan pozitif ilişki.

lanılabileceği düşünülen; $\mathrm{CD} 4{ }^{+} \mathrm{CD} 25^{\text {high }} \mathrm{FoxP}^{+}(63.17 \pm 22.61), \mathrm{CD}^{+} \mathrm{CD} 25^{\text {high }} \mathrm{CD} 152^{+}$ $(90.219 \pm 6.42)$ ve $\mathrm{CD} 4^{+} \mathrm{CD} 25^{\text {high }} \mathrm{CD} 127^{\text {low }}(84.84 \pm 7.78)$ yüzde oranları karşılaştırıldığında pozitif korelasyon görülmüştür (sırasıyla $r=0.34, p<0.05 ; r=0.93, p<0.02 ; r=$ $0.62, p<0.02)$.

\section{TARTIŞMA}

HBV enfeksiyonları, aşı ile korunmanın yaygınlaşması ve bulaşın önlenmesi için alınan tedbirlerin arttırılmasıyla dünya çapında görülme sıklığı azalmakla birlikte, neden olduğu iki milyar enfekte ve 240 milyon kronik HBV enfeksiyonlu birey nedeniyle başlıca halk sağlığı sorunlarından biri olmaya devam etmektedir ${ }^{19,20}$. Hepatit B enfeksiyonunun vücuda girişi ve inkübasyonundan başlayarak konakta izleyeceği seyir ve nasıl sonuçlanacağı; doğal ve kazanılmış immün yanıtın karşııklı etkileşimini içeren karmaşık bir düzen sonucu belirlenir. Günümüzde, KHB tedavisinde kullanılan ilaçlar HBV replikasyonunu baskılamalarına, karaciğerde enflamasyonu azaltmalarına, hastalığın progresyonunu yavaşlatmalarına ve karaciğer hastalığının remisyonunu sağlamalarına rağmen henüz virüsün eradikasyonunu sağlayacak bir tedavi bulunamamıştır ${ }^{21}$. 
Olası HBV tedavi hedeflerini belirlemedeki çalışmalar, HBV-immün sistem ilişkilerini ortaya koymaya, bu yolaklarda görev alan aracı moleküllerin ve özellikle de son 10 yılda tanımlanan, immünsupresif regülatör $T$ hücrelerin rolünü anlamaya yöneliktir ${ }^{22}$. Çalışmamızda, enfeksiyon etkenlerinin ve bunlara olan immünolojik yanıtın belirlenmesi gibi mikrobiyolojide daha geniş kullanım alanı bulmaya başlayan akım sitometrisi yöntemiyle hepatit B hastalarında periferik kan Treg hücre yüzdelerini ve salınan IL-10 sitokin düzeylerini saptayarak hastalığın tanı ve takibinde kullanılan diğer belirteçlerle karşılaştırdık.

Yapılan çalışmalarda, KHB hastalarının Treg hücreleri, AHB hastalarından \%33 daha yüksek bulunmuştur ${ }^{18,23}$. KHB hastalarının HBeAg pozitif kronik hepatit döneminde Treg yüzdelerinin $\mathrm{HBeAg}$ negatif kronik enfeksiyon dönemiyle karşılaştırıldığında belirgin olarak daha yüksek oluşu nedeniyle, hastalığın ağırlığını gösterecek bir prognostik belirteç olabileceği bildirilmiştir ${ }^{24}$. Zhi-Jun Su ve arkadaşlarının 2013 yılında KHB hastalarında yaptıkları çalışmada ${ }^{25}$, heparinize periferik kanda Treg ve $T_{17}$ yüzdeleri birlikte ölçülmüş, hastalar serum Tbil ve ALT düzeylerine göre ağır ve hafif KHB olarak iki grupta değerlendirilmiştir. Treg hücreler $\mathrm{CD} 4^{+} \mathrm{CD} 25^{\text {high }} \mathrm{CD} 127^{\text {low }}$ olarak seçildiğinde sağlıklı kontrollerin Treg yüzdeleri (\%5.69), ağır (\%7.66) ve hafif (\%6.72) KHB hastalarından istatistiksel olarak anlamlı ölçüde düşük bulunmuştur. Çalışmamızda, akut evredeki hastaların Treg hücre yüzdeleri normalin (\%2-4) alt sınırından daha düşük, HBeAg pozitif kronik enfeksiyon ve HBeAg pozitif kronik hepatit, HBeAg negatif kronik enfeksiyon ve HBeAg negatif kronik hepatit dönemindeki KHB hastalarındaki Treg hücre yüzdeleri ise sağlıklı kontrollerle karşılaştırıldığında anlamlı düzeyde yüksek bulunmuştur. AHB Treg hücre yüzdeleri ile tüm KHB gruplarınınkiler arasında istatistiksel olarak belirgin fark gözlenmiştir.

Aalaei-Andabili ve arkadaşları tarafından yapılan sistematik derlemede ${ }^{18}, 107$ viral kopya/ml üzerinde HBV DNA yüküne sahip hastaların daha düşük viral yüklü hastalarla karşılaştırıldığında Treg hücre yüzdelerinin anlamlı ölçüde yüksek bulunduğu, bu nedenle Treg hücre artışının HBV DNA yükü ile pozitif korelasyon gösterdiği bildirilmişitir. Çalışmamızda HBeAg pozitif kronik enfeksiyon $\left(2.96 \times 10^{7}\right.$ kopya/ml) ve HBeAg pozitif kronik hepatit $\left(1.12 \times 10^{5} \mathrm{kopya} / \mathrm{ml}\right)$ dönemi KHB hastalarında en yüksek HBV DNA yükü saptanırken bunu AHB hastaları izlemiştir (3.36 × 10 $\mathrm{kopya} / \mathrm{ml})$, HBeAg negatif kronik enfeksiyon ve HBeAg negatif kronik hepatit dönemindeki KHB hastalarının viral yükü ise daha düşük bulunmuştur (sırasıyla, $0.45 \times 10^{3} \mathrm{kopya} / \mathrm{ml}, 7.89 \times 10^{3} \mathrm{kopya} / \mathrm{ml}$ ). HBV DNA yükü ile Treg hücre yüzdesi arasında KHB hastalarında pozitif ilişki görülmüştür.

Berry ve arkadaşlarının yaptıkları çalışmada ${ }^{26}$, antienflamatuvar sitokin IL-10 düzeyinin artışılla immün yetmezlik ve akut karaciğer yetmezliğine ilerleme görüldüğü ve yüksek IL-10 seviyelerinin akut hepatitte kötü prognozla ilişkili olabileceği ileri sürülmüştür. Başka bir çalışmada, IL-10 gen polimorfizmi olan hepatit B hastalarında, daha düşük kapasitede IL-10 üretimine bağlı, asemptomatik taşıyıcılığın kronik progresif karaciğer hastalığı gelişiminden belirgin oranda daha yüksek görüldüğü rapor edilmiştir ${ }^{27}$. Akut hepatitte ve alevlenmede IL-10 seviyeleri yükselerek karaciğeri immün hasardan korurken muhtemelen viral persistansa neden olmaktadır, diğer taraftan kronik hepatitin geç fazında azala- 
rak, ancak devam eden immünolojik aktiviteye bağlı olarak sağlıklı kontrollere oranla yine de daha yüksek seviyede kalarak, immün regülasyonun yeniden oluşumunu sağlamaktadır. Çalışmamızda AHB hastalarının IL-10 seviyelerinin, hem sağlıklı kontrollerden hem de KHB hastalarından daha yüksek seviyede bulunmasının bu mekanizmaya bağlı olduğu düşüncesindeyiz. Anna Parfieniuk-Kowerda ve arkadaşlarının yaptığı derlemede ${ }^{28}$, sağlıklı kişilerde IL-10'un baskın olarak monositlerden salınırken persistant viral enfeksiyonlarda ve KHB hastalarında asıl kaynağın Treg hücreler olduğu, IL-10 düzeyinin HBsAg ile birlikte ölçümünün asemptomatik hepatit B taşıyıcılarını, fluktuan (dinamik) hepatit B hastalarından ayrımında kullanılabileceği sonucuna varılmıştır. Bizim çalışmamızda, HBeAg pozitif kronik hepatit dönemindeki KHB hastalarının serum IL-10 düzeyleri, HBeAg negatif kronik enfeksiyon düzeyinden anlamlı ölçüde yüksek bulunmuş ve bu bulgularla, literatürle de uyumlu olarak, HBeAg pozitif kronik hepatit dönemi hastalarının prognozlarının daha kötü olacağı düşünülmüştür. Zhi-Jun Su ve arkadaşlarının yaptıkları çalışmada ${ }^{25}$, IL-10 düzeylerinin sağlıklı kontrollerde (28.34), ağır (51.47) ve hafif (48.84) KHB hastalarından düşük olduğu görülmüştür. Bu çalışmada ayrıca karaciğer enflamasyonunun, ALT ve Tbil düzeylerinin Treg hücre, TGF- $\beta$ ve IL-10 düzeyleri ile ilişkiliyken, Th17 ile ilişkili olmadığı sonucuna varılmıştır. Bu bulgular çalışma sonuçlarımızla paralellik gösterirken, Zhi-Jun Su ve arkadaşlarının çalışmasında ${ }^{25}$ KHB gruplarının tedavi almış hastaları da içeren heterojen bir popülasyondan oluşması sonuçların karşılaştırmasını güçleştirmiştir.

Daha önce yapılan çalışmaların çoğunda Treg hücrelerini tanımlamak için CD4 ve CD25 belirteçleri kullanmıştır. Fakat CD25 fonksiyonel T hücreler tarafından da eksprese edilmektedir. Ayrıca CD25'in düşük ya da yüksek ekspresyonuna ilişkin net tanımlar da henüz mevcut değildir. Bu nedenle Treg düzeyini belirlemek için CD4 ve CD25 ile işaretlemenin doğruluğu yeterli değildir ${ }^{29}$. Güncel veriler doğrultusunda FoxP3, Treg hücreleri için en özgün ve en iyi işaretleyici olarak kabul edilmektedir. Ancak, FoxP3'ün hücre içinde eksprese edilmesi nedeniyle Treg hücrelerin bu belirtece göre izole edilmelerinin güç olması yüzeyde eksprese edilen başka belirteçlerin araştırılması gereğini doğurmuştur ${ }^{30}$. Insanda regülatör Foxp $3^{\text {high }} \mathrm{CD} 25^{\text {high }} \mathrm{CD} 4^{+} \mathrm{T}$ hücrelerin hafıza fenotiplerinde CD152 eksprese edilmektedir, yalnız $\mathrm{CD} 4^{+} \mathrm{CD} 25^{+}$hücrelerle karşılaştırıldığında CD152 pozitifliğinin Treg hücre oranlarıyla daha iyi korele bulunarak bu hücreleri tanımlamada kullanılabileceğini öne süren çalışmalar mevcuttur ${ }^{31}$. Son zamanlarda IL-7 reseptörün $\alpha$ zinciri olan CD127 tanımlanmıştır. Yetişkin kord ve periferik kanında CD4 ${ }^{+} \mathrm{CD} 25^{+} \mathrm{CD} 127^{\text {low }}$ hücrelerin yaklaşık \%90'ının FoxP3 eksprese ettiği, bu yeni sayılabilecek işaretleyici kullanılarak Treg hücreleri tanımlanabileceği gösterilmiştir ${ }^{32}$. Bu nedenlerle, çalışmamızda düzenleyici $T$ hücreleri belirlemek için $\mathrm{CD} 4^{+} \mathrm{CD} 25^{\text {high }}, \mathrm{CD} 4^{+} \mathrm{CD} 25^{\text {high }}$ FoxP3 $3^{+}, \mathrm{CD}^{+} \mathrm{CD} 25^{\text {high }} \mathrm{CD} 152^{+}$ ve $C D 4^{+} C D 25^{+} C D 127^{\text {low }}$ pozitifliği ayrı ayrı değerlendirilmiştir. CD4 $4^{+} \mathrm{CD} 25^{\text {high }}$ hücrelerin \%90 üzerinde bir oranla CD152 pozitifliğiyle, CD4 ${ }^{+}$CD2 $5^{\text {high }}$ hücrelerin yaklaşık \%85'inin aynı zamanda CD127 $7^{\text {low }}$ pozitifliğiyle Treg hücre belirlenmesinde kullanılabileceği düşünülmüştür. $\mathrm{CD}^{+} \mathrm{CD} 25^{\text {high }} \mathrm{FoxP}^{+}$hücreler ile hepatit B parametrelerinin korelasyonunun diğer yüzey belirteçlerine göre daha zayıf oluşunun; hücre içi boyama protokolü zorluğuna bağlı olduğu düşünülmüştür. 
Sonuç olarak, bu çalışmayla periferik kan Treg hücre ve IL-10 sitokin seviyelerinin hepatit B'nin ciddiyeti ve evresiyle ilişkili olduğu ve bir belirteç olarak kullanılabileceği gösterilmiştir. Treg hücre ölçümünde $\mathrm{CD} 4^{+} \mathrm{CD} 25^{\text {high }} \mathrm{FoxP} 3^{+} \mathrm{CD} 152^{+} \mathrm{CD} 127^{\text {low }}$ belirteçlerinin birlikte kullanılmasıyla daha güvenilir sonuçlar elde edilmektedir.

\section{ÇIKAR ÇATIŞMASI}

Yazarlar bu makale ile ilgili herhangi bir çıkar çatışması bildirmemişlerdir.

\section{KAYNAKLAR}

1. Lavanchy D. Hepatitis B virus epidemiology, disease burden, treatment, and current and emerging prevention and control measures. J Viral Hepat 2004; 11(2): 97-107.

2. Rehermann B, Nascimbeni M. Immunology of hepatitis B virus and hepatitis C virus infection. Nat Rev Immunol 2005; 5(3): 215-29.

3. Shadlar S, Hildt E. HBV life cycle: entry and morphogenesis. Viruses 2009; 1(2): 185-209.

4. Zhang $X$, Hou J, Lu M. Regulation of hepatitis B virus replication by epigenetic mechanisms and microRNAs. Front Genet 2013; 14(4): 202.

5. Gerlich WH. Medical virology of hepatitis B: how it began and where we are now. Virol J 2013; 10: 239.

6. Ay P, Torunoglu MA, Com S, Cipil Z, Mollahaliloglu S, Erkoc Y, et al. Trends of hepatitis B notification rates in Turkey, 1990 to 2012. Euro Surveill 2013; 18(47): 20636.

7. Xu D, Fu J, Jin L, Zhang H, Zhou C, Zou Z, et al. Circulating and liver resident CD4+ cd25+ regulatory T cells actively influence the antiviral immune response and disease progression in patients with hepatitis $\mathrm{B}$. J immunol 2006; 177(1): 739-47.

8. Oo YH, Weston CJ, Lalor PF, Curbishley SM, Withers DR, Reynolds GM, et al. Distinct roles for CCR4 and CXCR3 in the recruitment and positioning of regulatory T cells in the inflamed human liver. J Immunol 2010;1 84(6): 2886-98.

9. Stoop JN, van der Molen RG, Baan CC, van der Laan LJ, Kuipers EJ, Kusters JG, et al. Regulatory T cells contribute to the impaired immun response in patients with chronic hepatitis B virus infection. Hepatology 2005; 41(4): 771-8.

10. Das $A$, Ellis $G$, Pallant $C$, Lopes $A R$, Khanna $P$, Peppa $D$, et al. IL-10 producing regulatory $B$ cells in the pathogenesis of chronic hepatitis B virus infection. J Immunol 2012; 189(8): 3925-35.

11. Niu Y, Liu H, Yin D, Yi R, Chen T, Xue H, et al. The balance between intrahepatic IL-17(+) T cells and Foxp3(+) regulatory T cells plays an important role in HBV-related endstage liver disease. BMC Immunol 2011; 12: 47.

12. Yamaguchi T, Sakaguchi S. Regulatory T cells in immune surveillance and treatment of cancer. Semin Cancer Biol 2006; 16(2): 115-23.

13. Shevach EM. CD4+ CD25+ suppressor T cells: more questions than answers. Nat Rev Immunol 2002; 2(6): 389-400.

14. Suvas $S$, Kumaraguru U, Pack CD, Lee $S$, Rouse BT. CD4+CD25+T cells regulate virus-specific primary and memory CD8+ T cell responses. J Exp Med 2003; 198(6): 889-901.

15. European Association for the Study of the Liver. EASL 2017. Clinical Practice Guidelines on the management of hepatitis B virus infection. J Hepatol 2017; 67(2): 370-98.

16. Horvat RT, Tegtmeier GE, Çeviri: İyigün CP, Avcı IY. Hepatit B ve D virüsleri. Klinik Mikrobiyoloji (Manual of Clinical Microbiology) Çeviri Editörü; Başustaoğlu A, 9. Baskı, 2009, Atlas Kitapçılık, Ankara, Türkiye.

17. Aalaei-Andabili SH, Alavian SM. Regulatory T cells are the most important determinant factor of hepatitis $B$ infection prognosis: a systematic review and meta-analysis. Vaccine 2012; 30(38): 5595-602.

18. Baecher-Allan C, Viglietta V, Hafler DA. Human CD4_CD25_regulatory T cells. Semin Immunol 2004; 6: 89-98. 
19. Kaya S, Alanoğlu G, Polat M, Sipahi T. Süleyman Demirel Üniversitesi Tıp Fakültesi Kan Merkezi'nin 20002007 yllları tarama test sonuçları. SDÜ Tıp Fak Derg 2009; 16(2): 13-5.

20. Tavakolpour S, Alavian SM, Sali S. Manipulation of regulatory cells' responses to treatments for chronic hepatitis B virus. Hepat Mon 2016; 16(6): e37927.

21. Bertoletti A, Gehring AJ. Immune therapeutic strategies in chronic hepatitis B virus enfection: virus or inflamation control? PloS Pathog 2013; 9812: e1003784.

22. Duyan S, Kılıç A, Yılmaz S, Ardıç N. Genişlemiş spektrumlu beta-laktamazların akım sitometrisi yöntemiyle hızlı tespiti. Mikrobiyol Bul 2015; 49(4): 600-8.

23. Peng G, Li S, Wu W, Sun Z, Chen Y, Chen Z. Circulating CD4+ CD25+ regulatory T cells correlate with chronic hepatitis B infection. Immunology 2008; 123(1): 57-65.

24. Wang X, Ning Q. Immune mediated liver failure. EXCLI J 2014; 13: 1131-44.

25. Su ZJ, Yu XP, Guo RY, Ming DS, Huang LY, Su ML, et al. Changes in the balance between Treg and Th17 cells in patients with chronic hepatitis B. Diagn Microbiol Infect Dis 2013; 76(4): 437-44.

26. Antoniades CG, Berry PA, Wendon JA, Vergani D. The importance of immune dysfunction in determining outcome in acute liver failure. J Hepatol 2008; 49(5): 845-61.

27. Miyazoe S, Hamasaki K, Nakata K, Kajiya Y, Kitajima K, Nakao K, et al. Influence of interleukin-10 gene promoter polymorphisms on disease progression in patients chronically infected with hepatitis $B$ virus. Am J Gastroenterol 2002; 97(8): 2086-92.

28. Parfieniuk-Kowerda A, Jaroszewicz J, Flisiak R. Immune regulation and viral diversity as correlates of natural and treatment induced immune control in persistent hepatitis B virus (HBV) infection. Clin Exp Hepatol 2015; 1(2): 35-8.

29. Sakaguchi S, Sakaguchi N, Asano M, Itoh M, Toda M. Immunologic self-tolerance maintained by activated T cells expressing IL-2 receptor alpha-chains (CD25). Breakdown of a single mechanism of self-tolerance causes various autoimmune diseases. J Immunol 1995; 155(3): 1151-64.

30. Ziegler SF. FOXP3: of mice and men. Annu Rev Immunol 2006; 24: 209-26.

31. Bour-Jordan H, Grogan JL, Tang Q, Auger JA, Locksley RM, Bluestone JA. CTLA-4 regulates the requirement for cytokine-induced signals in T(H)2 lineage commitment. Nat Immunol 2003; 4(2): 182.

32. Liu W, Putnam AL, Xu-Yu Z, Szot GL, Lee MR, Zhu S, et al. CD127 expression inversely correlates with FoxP3 and suppressive function of human CD4+ T reg cells. J Exp Med 2006; 203(7): 1701-11. 